\title{
Leaf mineral concentrations of Erica arborea, Juniperus communis and Myrtus communis growing in the proximity of a natural $\mathrm{CO}_{2}$ spring
}

\author{
JOSEP PEÑUELAS*, I OLANDA FILELLA* and ROBERTO TOGNETTI† \\ *Unitat Ecofisiologia CSIC, Centre de Recerca Ecològica i Aplicacions Forestals, Facultat de Ciències, Universitat Autònoma, \\ 08193 Bellaterra (Barcelona), Spain, tDipartimento di Scienze Animali, Vegetali e dell'Ambiente (SAVA), Università degli \\ Studi del Molize, via De Sanctis, I-86100, Campobasso, Italy
}

\begin{abstract}
Leaf mineral concentrations of co-occurring Erica arborea, Juniperus communis and Myrtus communis were measured at bimonthly intervals throughout a year in a natural $\mathrm{CO}_{2}$ spring and in a nearby control site with similar soil chemistry in a Mediterranean environment. There were different responses to the elevated $\left[\mathrm{CO}_{2}\right]$ (c. $700 \mu \mathrm{L} \mathrm{L}^{-1}$ ) of the spring site plants depending on the element and the species. In the $\mathrm{CO}_{2}$ spring site $\mathrm{K}, \mathrm{Ca}, \mathrm{Mg}, \mathrm{Mn}, \mathrm{Al}, \mathrm{Fe}$, and $\mathrm{Ti}$ leaf concentrations and the ratio $\mathrm{C} / \mathrm{N}$ showed significant greater values in at least one or two of the three species. Leaf $\mathrm{S}$ concentration were greater in all three species. Leaf concentrations of $\mathrm{N}, \mathrm{Sr}, \mathrm{Co}$, and $\mathrm{B}$ were lower in at least one or two species, and those of $\mathrm{C}$ and $\mathrm{Ba}$ were lower in all the three studied species near the $\mathrm{CO}_{2}$ spring. $\mathrm{P}, \mathrm{Na}, \mathrm{Zn}, \mathrm{Si}, \mathrm{Cu}, \mathrm{Ni}, \mathrm{Cr}, \mathrm{Pb}, \mathrm{Mo}, \mathrm{V}$ and $\mathrm{Cd}$ leaf concentrations and the specific leaf area (SLA, measured in Myrtus communis) did not show any consistent or significant pattern in response to the elevated $\left[\mathrm{CO}_{2}\right]$ of the spring site. There was a slight trend towards maximum concentrations of most of these elements during autumn-winter and minimum values during the spring season, especially in Myrtus communis. Multivariate principal component analyses based on the leaf elemental concentrations clearly differentiated the two sites and the three species. Lower concentrations at the spring site were not the result of a dilution effect by increased structural or nonstructural carbon. In contrast to most experimental studies of $\mathrm{CO}_{2}$ enrichment, mainly conducted for short periods, several of these elements had greater concentrations in the $\mathrm{CO}_{2}$ spring site. Nutrient acclimation and possible causes including decreased nutrient export, increased nutrient uptake capacity, photosynthetic down-regulation, Mediterranean water stress, and higher $\mathrm{H}_{2} \mathrm{~S}$ concentration in the spring site are discussed.
\end{abstract}

Keywords: acclimation, elevated $\mathrm{CO}_{2}$ concentrations, macronutrients, Mediterranean shrubs, trace elements

Received 3 May 2000; revised version received and accepted 18 September 2000

\section{Introduction}

In most $\mathrm{CO}_{2}$ experiments, nutrient analyses of the studied plant materials have been restricted to nitrogen; yet in spite of this restriction, they have been used to explain general nutritional effects on physiological or growth responses. In the few experiments where concentrations of a ranger of elements have been analysed, increased atmospheric $\mathrm{CO}_{2}$ concentrations

Correspondence: Josep Peñuelas, fax +34/93-5811312, e-mail Penuelas@uab.es
( $\left.\left[\mathrm{CO}_{2}\right]\right)$ have often been observed to decrease the mineral concentrations (per unit dry mass) of various plant tissues. These decreases have been suggested to be mainly a consequence of mineral uptake not increasing at the same rate as dry matter accumulation, i.e. of dilution by growth (inadequate nutrient availability) or/ and of increased amounts of nonstructural carbohydrates (mainly starch), but also of lower transpiration rates or changes in nutrient allocation pattern (Norby et al. 1986; O'Neill etal. 1987a; Eamus \& Jarvis 1989; Peñuelas \& 
Matamala 1990, 1993; Woodin etal. 1992; Conroy \& Hocking 1993; Linder \& McDonald 1993; Overdieck 1993; Ceulemans \& Mousseau 1994; Rogers et al. 1994; Cotrufo et al. 1998; Curtis \& Wang 1998; Roberntz \& Linder 1999). Some studies have suggested that such a nutrient dilution may produce a reduction in photosynthetic rates and limit the long-term growth response to $\mathrm{CO}_{2}$ (Larigauderie et al. 1988; Brown 1991; Woodin et al. 1992) especially in ecosystems that are poor in nutrients, such as the arctic tundra (Oechel et al. 1994).

However, vegetation is not likely to be suddenly subjected to a dramatic increase in atmospheric $\left[\mathrm{CO}_{2}\right]$ such as that typically imposed in short-term $\mathrm{CO}_{2-}$ enrichment experiments conducted in greenhouses and different kind of chambers during studies of global environmental change studies. Different plant physiological processes could adjust or acclimate to a gradual increase in $\mathrm{CO}_{2}$ at different rates over periods ranging from hours to years, and generations (Eamus \& Jarvis 1989; Saxe etal. 1998). Despite this possibility of longterm acclimation, however, very few studies of the interactions between $\mathrm{CO}_{2}$ and nutrients have extended beyond a single growing season. Interestingly, in some of the few long-term studies the initial reductions in the leaf concentrations of $\mathrm{Mn}, \mathrm{N}, \mathrm{Ca}$ and $\mathrm{Mg}$ have been found to disappear gradually over the years (Peñuelas et al. 1997).

Natural $\mathrm{CO}_{2}$ springs offer an opportunity to study the long-term responses of entire plant communities to enriched $\left[\mathrm{CO}_{2}\right]$, as they are unique environments of intrinsic ecological interest (Miglietta et al. 1993; Körner \& Miglietta 1994; Hättenschwiler et al. 1997). Oak trees (Quercus spp.) at the $\mathrm{CO}_{2}$ spring of Bossoleto (Italy) have shown various responses to elevated $\left[\mathrm{CO}_{2}\right]$ (Johnson et al. 1997; Tognetti etal. 1998). Much less information is available for the shrub layer (Jones et al. 1995; Tognetti 1999), which constitutes the great bulk of the vegetation in these Mediterranean-type ecosystems (di Castri 1981). Plant communities of Mediterranean-type ecosystems are expected to be particularly sensitive to the ongoing increase in atmospheric $\mathrm{CO}_{2}$ concentrations (IPCC 1996). They are likely to face more severe drought conditions in the future, because of the increase in mean temperature and the concurrent decrease in precipitation at Mediterranean latitudes as forecast by General Circulation Models (Kattenburg et al. 1996).

The aim of this study was to determine whether leaf elemental concentrations of three common and widespread Mediterranean macchia shrub species, Erica arborea L., Myrtus communis L. and Juniperus communis L., grown in the proximity of a natural $\mathrm{CO}_{2}$ spring differ from those of comparable shrubs of the same species grown nearby but exposed to ambient $\left[\mathrm{CO}_{2}\right]$. Specifically, the study posed the question of whether leaf nutrient dilution occurs at elevated $\left[\mathrm{CO}_{2}\right]$ or, on the contrary, if there is a long-term adjustment or acclimation of leaf mineral concentration over a period of several generations. An extensive list of elements was analysed that included macronutrients such as $\mathrm{N}, \mathrm{P}, \mathrm{S}, \mathrm{K}, \mathrm{Mg}$, Ca and $\mathrm{Fe}$, micronutrients such as $\mathrm{Mn}, \mathrm{Zn}, \mathrm{Cu}, \mathrm{Mo}, \mathrm{Ni}, \mathrm{Co}$ and $\mathrm{B}$, and also heavy metals, such as $\mathrm{Cd}, \mathrm{Pb}, \mathrm{Cr}, \mathrm{Co}$, which are generally not essential for plant function.

\section{Materials and methods}

\section{Site description and plant material}

Leaf samples were obtained from Erica arborea, Myrtus communis and Juniperus communis growing at a natural $\mathrm{CO}_{2}$ spring near Lajatico (Pisa, Italy) called 'I Borboi' $\left(43^{\circ} 26^{\prime} \mathrm{N}, 10^{\circ} 42^{\prime} \mathrm{E}\right)$. A full description of the geology of the site can be found in Panichi \& Tongiorgi (1975). The $\mathrm{CO}_{2}$-enriched area extends over $0.7 \mathrm{ha}$. It is covered by a coppiced stand dominated by Quercus ilex L. Quercus pubescens Willd. and Arbutus unedo L. Several other tree species, e.g. Quercus cerris L. and Fraxinus ornus L., are represented by scattered individuals. Shrubs include the species studied here and Smilax aspera L., Cytisus scoparius L., Cistus salvifolius L., Genista sp., Ligustrum vulgare L., Pistacia lentiscus L. and Phillyrea latifolia L. The $\mathrm{CO}_{2}$ spring is located on the N-facing slope (20\%) of a hill near the bottom of a small valley about $200 \mathrm{~m}$ a.s.l. (Raiesi 1998a,b; Tognetti 1999). Almost pure $\mathrm{CO}_{2}$ is emitted from a series of vents located along a narrow seasonal creek and the $\left[\mathrm{CO}_{2}\right]$ tends to decrease upslope (see Tognetti et al., 2000a, for a map of the site). The vents emit small amount of $\mathrm{H}_{2} \mathrm{~S}$, but its concentration never exceeds a level of $0.04 \mathrm{umol} \mathrm{mol}^{-1}$ and is not considered to be harmful to plants (Raiesi 1998a,b; Schulte 1998). Plants around the $\mathrm{CO}_{2}$ spring are exposed to daytime $\left[\mathrm{CO}_{2}\right]$ of about $700 \mu \mathrm{mol} \mathrm{mol}^{-1}$ throughout the year with shortterm variations between 500 and $1000 \mu \mathrm{mol} \mathrm{mol}{ }^{-1}$ depending on wind speed and convective turbulence. The $\left[\mathrm{CO}_{2}\right]$ varies little between different heights within the canopy (Hättenschwiler et al. 1997).

Leaf samples were collected from individuals growing close to the $\mathrm{CO}_{2}$ spring. Additional measurements were made at a control site chosen along the same creek about $150 \mathrm{~m}$ upstream; thus roots of selected plants experienced similar soil environments and branches the same aerial environment, except for $\left[\mathrm{CO}_{2}\right]$ and amounts of sulphur-containing gases lower than $0.04 \mu \mathrm{mol} \mathrm{mol}^{-1}$ (Schulte 1998). The area has noncalcareous, brown loamy clay soils, developed from calcareous marl (pH 6-7), and total soil $\mathrm{N}$ and $\mathrm{C} / \mathrm{N}$ ratio in the forest floor and mineral horizon $(0-10 \mathrm{~cm})$ are comparable in both the spring and control areas (Raiesi 1998a,b). The climate is typical Mediterranean, with cool, wet winters and hot, dry summers (Tognetti 1999). At both sites, six replicate 
shrubs of similar exposure were selected for each species and sampling month. Measurements were made on current-year mature leaves from sunny shoots in the upper third of the canopy. The mean leaf longevity of the three species is 2-3 years, buds break in April-May and leaf abcision takes place also in April-May. Only plants and leaves in the same stage of development were sampled, in order to avoid possible elemental differences resulting from phenological effects.

\section{Leaf chemical composition}

Every two months during one year, from October 1996 to September 1997, shoots were collected from six individuals (not necessarily the same ones each month) of each species (Erica arborea, Myrtus communis and Juniperus communis) at each site ( $\mathrm{CO}_{2}$ spring and control), early in the morning. The shoots were then transported to the laboratory and oven-dried at $60^{\circ} \mathrm{C}$ to constant weight (dry weight, DW). Leaf areas of Myrtus communis were measured with a LiCor Model 3100 leaf area meter (LICOR, Lincoln, NE, USA) before drying. Afterwards, specific leaf area (SLA) was calculated. Thereafter, 12 leaves of the same stage of development were bulked for each plant at each sampling date and then ground to a fine powder in a mill.

Carbon $(\mathrm{C})$ and nitrogen $(\mathrm{N})$ leaf concentrations were analysed using an elemental analyser (Model NA 1500, Carlo Erba, Milano, Italy), using the standard configuration for those determination. Leaf concentrations of 23 elements (Ca, K, Mg, Al, Fe, $\mathrm{Na}, \mathrm{Mn}, \mathrm{Zn}, \mathrm{Pb}, \mathrm{Ti}, \mathrm{Sr}, \mathrm{Ba}$, $\mathrm{Cd}, \mathrm{Co}, \mathrm{Cu}, \mathrm{Mo}, \mathrm{Ni}, \mathrm{V}, \mathrm{Cr}, \mathrm{S}, \mathrm{P}, \mathrm{Si}$ and B) were measured on subsamples (about $100 \mathrm{mg}$ ) of ground leaves. Samples were digested in a microwave Whirlpool AVM 635 using open fluorinated ethylene propylene flasks (Nalge Company) with an acid solution of 2:1 nitric and perchloric acids $(60 \%)$. Once samples were efficiently oxidized $\left(0.5 \mathrm{~cm}^{3}\right.$ remaining), they were diluted with $20 \mathrm{~mL}$ of perchloric acid (3\%). Flasks were stoppered and shaken by hand to mix of the contents. The sample solution was then poured into a polystyrene sample tub, placed in an autosampler carousel and analysed for the elements by ICAP-AES (inductively coupled argon plasma emission spectrometer) Polyscan Thermo Jarrel ASH Model 61 E (Peñuelas \& Matamala 1993). Quality control was ensured by including a reference sample every 10 samples analysed. Readings were accepted when reference samples were within a 5\% range of known values for macroelements such as $\mathrm{N}, \mathrm{P}, \mathrm{K}$ or $\mathrm{Ca}$ and $10 \%$ range for microelements.

\section{Statistical analyses}

Within each species, two-way analyses of variance (anova) with sampling date and site (with different
$\left.\left[\mathrm{CO}_{2}\right]\right)$ as the main effects were conducted for all element concentrations after testing for normality and homogeneity of variance. A repeated-measures analysis was not considered appropriate because the same shrubs were not sampled over the sampling time period. Differences amongst the three species were also tested with anovas. Multivariate principal component analyses were conducted with the different element concentrations as variables. They were conducted on both the matrix of correlations and the matrix of covariance, i.e. without and with correction by mean, respectively. Statistical analyses were conducted using Statistical program packages Statview 4.5 (Abacus Concepts Inc., Berkeley, CA) and SYSTAT 5.2 (SYSTAT Inc., Evanston, IL).

\section{Results}

There were significant differences amongst species for most elements $(P<0.01$, ANOVA). Myrtus communis had the lowest leaf concentration of $\mathrm{Mn}, \mathrm{Fe}, \mathrm{S}, \mathrm{Al}, \mathrm{Ti}, \mathrm{C}$ and $\mathrm{Ba}$, and the greatest leaf concentrations of $\mathrm{Mg}, \mathrm{K}$, and $\mathrm{N}$ (Figs 1,2). Erica arborea had the lowest leaf concentrations of $\mathrm{Ca}, \mathrm{Co}$ and $\mathrm{Sr}$ and the greatest leaf concentrations of $\mathrm{Mn}, \mathrm{Fe}, \mathrm{Al}, \mathrm{Ti}, \mathrm{C}$ and $\mathrm{B}$. Juniperus communis had the lowest leaf concentrations of $\mathrm{N}$ and $\mathrm{B}$ and the greatest leaf concentrations of $\mathrm{Ca}, \mathrm{S}, \mathrm{Co}$ and $\mathrm{Sr}$ (Figs 1,2).

There were different responses to site (and therefore $\left.\left[\mathrm{CO}_{2}\right]\right)$ depending on the element and the species. In the $\mathrm{CO}_{2}$ spring site, $\mathrm{Ca}, \mathrm{K}, \mathrm{Mg}, \mathrm{Mn}, \mathrm{Al}, \mathrm{Fe}$ and $\mathrm{Ti}$ leaf concentrations were higher in one or two of the three species and $\mathrm{S}$ concentration was greatly higher in all the three studied species (Fig.1). Leaf concentrations of $\mathrm{N}$, $\mathrm{Sr}, \mathrm{Co}$ and $\mathrm{B}$ were lower in one or two species, and those of $\mathrm{C}$ and $\mathrm{Ba}$ were lower in all the three studied species in the $\mathrm{CO}_{2}$ spring site (Fig. 2). The leaf concentrations of $\mathrm{P}$, $\mathrm{Na}, \mathrm{Zn}, \mathrm{Si}, \mathrm{Cu}, \mathrm{Ni}, \mathrm{Cr}, \mathrm{Pb}, \mathrm{Mo}, \mathrm{V}$ and $\mathrm{Cd}$ did not show any consistent or significant pattern (Table 1). The SLA of Myrtus communis did not either show any clear difference between sites (data not shown).

Results of statistical analyses for site $\left(\left[\mathrm{CO}_{2}\right]\right)$ and month as sources of variation are summarized in Table 2. The strongest site differences in leaf element concentration were found for Juniperus communis. In this species, plants grown at the high $\left[\mathrm{CO}_{2}\right]$ of the spring site had greater concentrations of $\mathrm{Ca}(10 \%), \mathrm{Mg}(21.25 \%), \mathrm{Mn}$ $(27.7 \%), \mathrm{Fe}(22.54 \%), \mathrm{K}(42.4 \%), \mathrm{S}(699 \%), \mathrm{Al}(41.7 \%), \mathrm{Zn}$ $(43.48 \%)$ and $\mathrm{Ti}(173.4 \%)$ and lower concentrations of $\mathrm{C}$ $(1.86 \%)$, Ba $(52.94 \%)$ and Co $(24.19 \%)$ (Tables 1,2, Figs 1,2). In Myrtus communis plants grown at the high $\left[\mathrm{CO}_{2}\right]$ of the spring site had greater leaf concentrations only of $\mathrm{Mg}(28.7 \%), \mathrm{Mn}(115 \%)$, and S (74.2\%), and lower concentrations of C (3.54\%), N (17.7\%), Ba (62.5\%), Sr (25\%), P (15.85\%), B (20\%) and Cr (50\%) (Tables 1,2, 

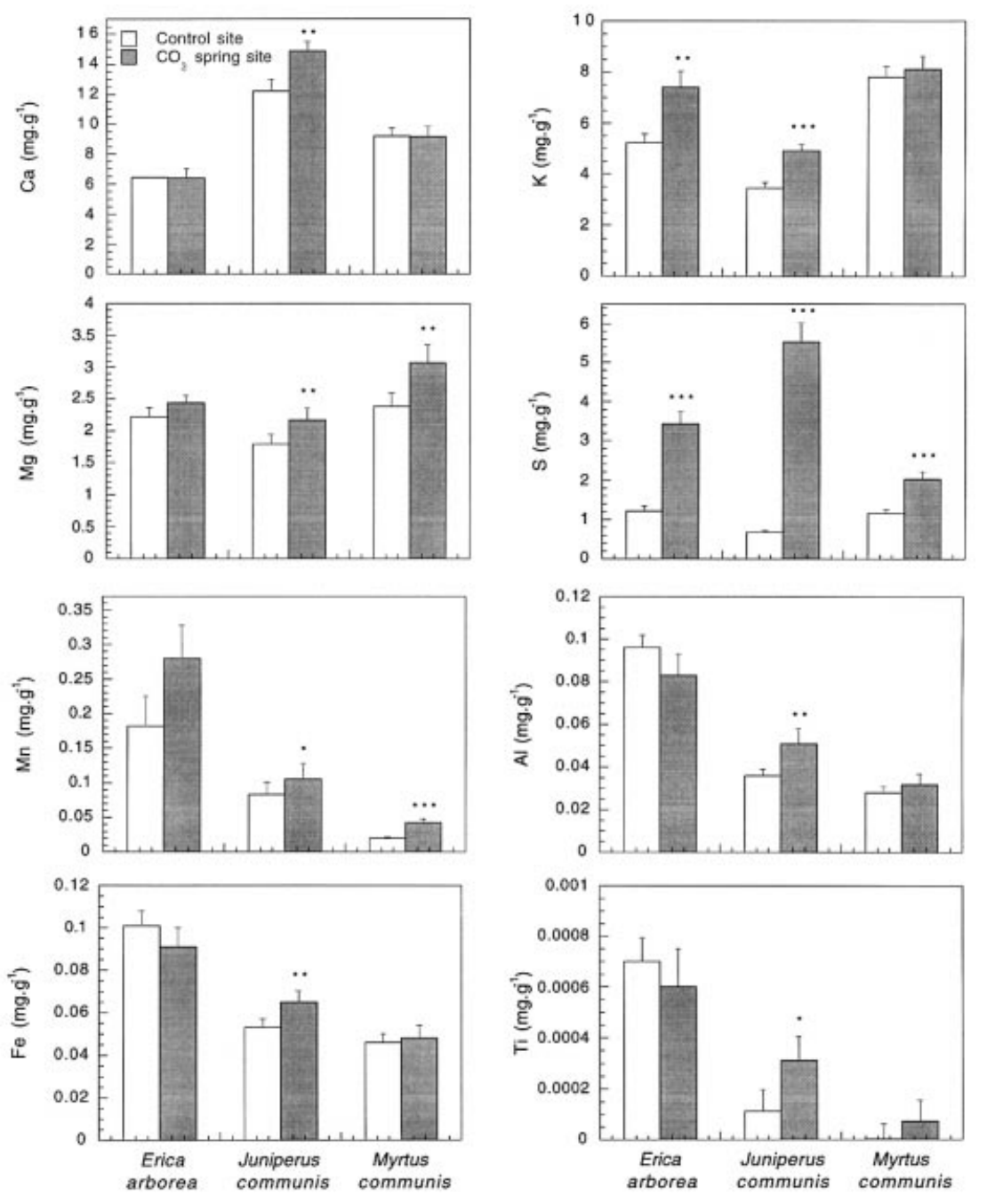

Fig. 1 Annual averages of the leaf elemental concentrations that were greater under the elevated $\left[\mathrm{CO}_{2}\right]$ of the spring site than in the control site, in at least one of the three studied shrub species. Error bars are \pm SEM. $n=6$ month averages, each one calculated for six plants (several leaves pooled together for each one). $\quad{ }^{*} P<0.05, \quad{ }^{* *} P<0.001$, ${ }_{* * *} P<0.001$ in the ANOVA for site effect.
Figs 1,2). In Erica arborea, plants grown at the high $\left[\mathrm{CO}_{2}\right]$ of the spring site had greater concentrations only of $\mathrm{K}$ $(41.97 \%), \mathrm{S}(182.27 \%)$ and $\mathrm{P}(21.32 \%)$, and lower concentrations of C (3.14\%), Ba (31.25\%), Sr (20\%) and B (29.11\%) (Tables 1,2, Figs 1,2). Regarding ratios between element concentrations, greater values of C/N (16\%, $P<0.01$ anova, data not shown) were found only in Myrtus communis.

The concentrations of many elements differed significantly among the sampling months (Table 2, Figs 3,4). However, the three shrub species did not display consistent seasonal changes, except for a slight trend towards minimum values in spring (youngest leaves) and maxima in autumn-winter (mature leaves) for most elements, especially evident in Myrtus communis and less clear in Erica arborea (Figs 3,4). The analyses revealed some statistically significant interactions between $\mathrm{CO}_{2}$ enrichment and month but not a clear general interaction (Table 2, Figs 3,4)

Principal components, calculated from the matrix of correlation for concentration of all the studied elements, resulted in a first factor PC1 $(22.4 \%$ of variance explained) that varied directly with $\mathrm{Na}, \mathrm{Al}, \mathrm{B}, \mathrm{Fe}, \mathrm{C}$, $\mathrm{Ti}$ and $\mathrm{Mn}$, and inversely with $\mathrm{P}, \mathrm{Sr}, \mathrm{Ca}$, and $\mathrm{Co}$, a second factor PC2 (11.86\% of variance explained) that varied with species, and a third factor PC3 $(9.29 \%$ of variance explained) that varied with site and therefore $\left[\mathrm{CO}_{2}\right]$ (also with leaf $\mathrm{S}$ concentrations that were much higher in plants of the $\mathrm{CO}_{2}$ spring site) (Fig. 5). The plot of PC2 vs. PC1 separated the three species very well, and the plot of PC3 vs. PC2 separated the two sites well (Fig. 6). Therefore, the three species and the control and the $\mathrm{CO}_{2}$ spring sites exhibited clear differences in their leaf elemental concentrations and could be distinguished 
Fig. 2 Annual average of the leaf elemental concentrations that were lower under the elevated $\left[\mathrm{CO}_{2}\right]$ of the spring site than in the control site, in at least one of the three studied shrub species. Error bars are \pm SEM. $n=6$ month averages, each one calculated for 6 plants (several leaves pooled together for each one). ${ }^{*} P<0.05$, ${ }^{* *} P<0.001,{ }^{* * *} P<0.001$ in the ANOVA for site effect.
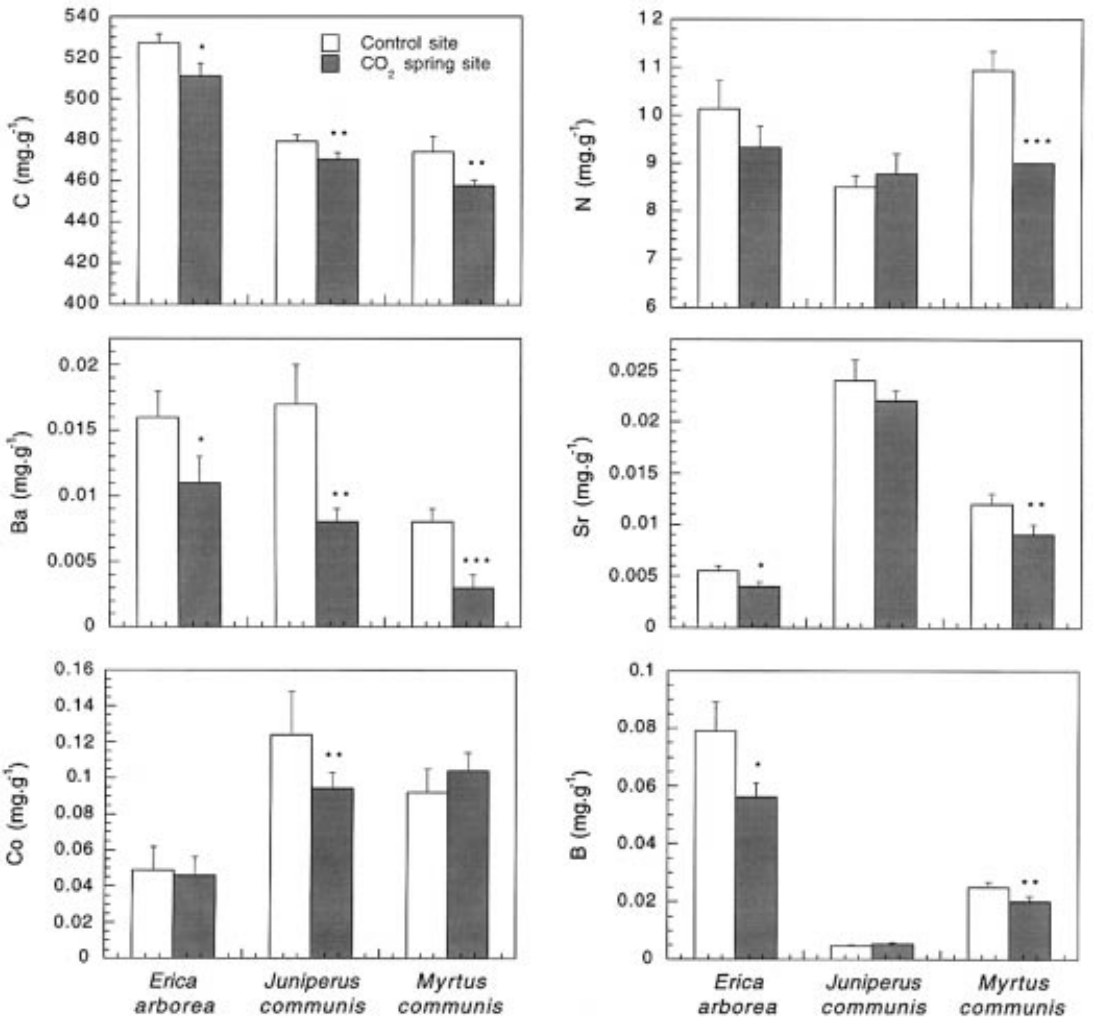

Table 1 Annual average leaf concentrations ( $\left.\mu \mathrm{g} \mathrm{g}^{-1} \mathrm{dwt}\right)( \pm \mathrm{SEM})$ of those elements that did not present consistent increase or decrease change under the elevated $\mathrm{CO}_{2}$ concentrations of the spring site. Different letters indicate significant differences $(P<0.05$ ANOVA) for site effect treatment. $n=6$ month averages, each one calculated for six plants (several leaves pooled together for each one)

\begin{tabular}{|c|c|c|c|c|c|c|}
\hline & \multicolumn{2}{|l|}{ Erica arborea } & \multicolumn{2}{|c|}{ Juniperus communis } & \multicolumn{2}{|l|}{ Myrtus communis } \\
\hline & Control & Spring & Control & Spring & Control & Spring \\
\hline $\mathbf{P}$ & $394^{\mathrm{a}}( \pm 23)$ & $478^{\mathrm{b}}( \pm 46)$ & $672( \pm 35)$ & $700( \pm 37)$ & $650^{\mathrm{a}}( \pm 41)$ & $547^{\mathrm{b}}( \pm 28)$ \\
\hline $\mathrm{Na}$ & $740( \pm 65)$ & $684( \pm 59)$ & $72( \pm 22)$ & $65( \pm 15)$ & $133( \pm 18)$ & $133( \pm 19)$ \\
\hline $\mathrm{Zn}$ & $27( \pm 3)$ & $26( \pm 3)$ & $23^{\mathrm{a}}( \pm 2)$ & $33^{\mathrm{b}}( \pm 4)$ & $32( \pm 7)$ & $25( \pm 1)$ \\
\hline Si & $24( \pm 3)$ & $23( \pm 3)$ & $19( \pm 6)$ & $27( \pm 7)$ & $2( \pm 2)$ & $2( \pm 3)$ \\
\hline $\mathrm{Cu}$ & $4.5( \pm 0.29)$ & $6( \pm 0.37)$ & $4( \pm 2)$ & $11( \pm 8)$ & $8.9( \pm 1)$ & $9.1( \pm 1)$ \\
\hline $\mathbf{N i}$ & $2( \pm 0.48)$ & $2( \pm 0.45)$ & $1( \pm 0.3)$ & $2( \pm 0.3)$ & $0.7( \pm 0.1)$ & $0.5( \pm 0.1)$ \\
\hline $\mathrm{Cr}$ & $1( \pm 1)$ & $2( \pm 1)$ & $2( \pm 0.48)$ & $2( \pm 1)$ & $4^{\mathrm{a}}( \pm 1)$ & $2^{\mathrm{b}}( \pm 0.4)$ \\
\hline $\mathrm{Pb}$ & $0( \pm 0.46)$ & $0.38( \pm 1)$ & $2( \pm 1)$ & $1( \pm 1)$ & $1.4( \pm 1)$ & $0.5( \pm 0.5)$ \\
\hline Mo & $0.8( \pm 0.16)$ & $1( \pm 0.23)$ & $0.87( \pm 0.17)$ & $0.48( \pm 0.1)$ & $0.7( \pm 0.13)$ & $0.5( \pm 0.1)$ \\
\hline $\mathbf{V}$ & $0.068( \pm 0.07)$ & $0.15( \pm 0.063)$ & $0.19( \pm 0.08)$ & $0.21( \pm 0.1)$ & $0.22( \pm 0.1)$ & $0.27( \pm 0.1)$ \\
\hline Cd & $0.12( \pm 0.07)$ & $0.096( \pm 0.067)$ & $0.011( \pm 0.06)$ & $0.083( \pm 0.04)$ & $0.057( \pm 0.08)$ & $0.24( \pm 0.1)$ \\
\hline
\end{tabular}

on the basis of multivariate principal component analysis.

\section{Discussion}

Most of the element concentrations in the leaves differed significantly among sampling dates as expected for leaves in different developmental stages (e.g. Myre \&
Camiré 1996). However, the most important finding of this study is the observation that, even though soil chemistry does not apparently differ between soils at the $\mathrm{CO}_{2}$ spring and control sites (Raiesi 1998a,b), there were significant differences in leaf elemental concentrations between the two sites. These differences were likely linked to the different $\left[\mathrm{CO}_{2}\right]$. Another important observation is the higher leaf concentrations of many elements, 
Table 2 Significance of $P$-values (using two-way ANOVA) associated with the different sources of variation $\left(\mathrm{CO}_{2}\right.$ concentration, month of the year and interaction effects) for mineral concentration in the leaves of Erica arborea, Juniperus oxycedrus and Myrtus communis

\begin{tabular}{|c|c|c|c|c|c|c|c|c|c|}
\hline & \multicolumn{3}{|c|}{ Erica arborea } & \multicolumn{3}{|c|}{ Juniperus communis } & \multicolumn{3}{|c|}{ Myrtus communis } \\
\hline & $\mathrm{CO}_{2}$ & Month & $\mathrm{CO}_{2} \times$ Month & $\mathrm{CO}_{2}$ & Month & $\mathrm{CO}_{2} \times$ Month & $\mathrm{CO}_{2}$ & Month & $\mathrm{CO}_{2} \times$ Month \\
\hline $\mathbf{N}$ & NS & NS & NS & NS & NS & NS & $<0.001$ & 0.002 & NS \\
\hline $\mathrm{C}$ & 0.032 & 0.084 & NS & NS & 0.042 & NS & 0.019 & NS & NS \\
\hline $\mathrm{Ca}$ & NS & 0.063 & NS & 0.003 & 0.01 & NS & NS & 0.002 & NS \\
\hline $\mathbf{K}$ & 0.004 & 0.033 & NS & $<0.001$ & 0.002 & 0.002 & NS & 0.008 & NS \\
\hline Mg & NS & NS & NS & 0.005 & 0.013 & $<0.001$ & $<0.001$ & $<0.001$ & 0.036 \\
\hline$S$ & $<0.001$ & NS & NS & $<0.001$ & 0.083 & 0.069 & $<0.001$ & NS & NS \\
\hline $\mathrm{Na}$ & NS & NS & 0.048 & NS & $<0.001$ & $<0.001$ & NS & NS & 0.069 \\
\hline $\mathbf{P}$ & 0.011 & $<0.001$ & 0.025 & NS & $<0.001$ & NS & $<0.001$ & $<0.001$ & NS \\
\hline Mn & NS & NS & NS & 0.075 & $<0.001$ & 0.059 & $<0.001$ & 0.039 & 0.058 \\
\hline Co & NS & $<0.001$ & NS & 0.082 & $<0.001$ & $<0.001$ & NS & NS & NS \\
\hline Al & NS & NS & NS & 0.029 & 0.008 & NS & NS & NS & NS \\
\hline $\mathrm{Fe}$ & NS & NS & NS & 0.042 & 0.038 & 0.073 & NS & NS & NS \\
\hline $\mathrm{Zn}$ & NS & 0.004 & NS & 0.064 & NS & NS & NS & NS & NS \\
\hline $\mathrm{Pb}$ & NS & NS & NS & NS & NS & NS & NS & NS & 0.099 \\
\hline $\mathrm{Ti}$ & NS & NS & NS & 0.085 & NS & NS & NS & NS & NS \\
\hline $\mathrm{Sr}$ & 0.066 & 0.012 & NS & NS & 0.072 & NS & 0.018 & 0.053 & NS \\
\hline Ва & 0.07 & NS & NS & 0.004 & NS & NS & $<0.001$ & NS & NS \\
\hline Cd & NS & NS & NS & NS & NS & NS & NS & NS & NS \\
\hline $\mathrm{Cu}$ & NS & 0.001 & NS & NS & NS & NS & NS & NS & 0.018 \\
\hline Mo & NS & NS & NS & 0.031 & 0.005 & NS & NS & NS & NS \\
\hline $\mathrm{Ni}$ & NS & 0.016 & 0.077 & NS & NS & NS & NS & NS & 0.067 \\
\hline V & NS & NS & NS & NS & 0.017 & NS & NS & NS & NS \\
\hline $\mathrm{Cr}$ & NS & 0.005 & NS & NS & 0.001 & NS & $<0.001$ & 0.005 & 0.004 \\
\hline $\mathrm{Si}$ & NS & 0.037 & NS & NS & NS & NS & NS & NS & NS \\
\hline B & 0.021 & 0.099 & 0.014 & NS & NS & NS & 0.046 & 0.085 & NS \\
\hline
\end{tabular}

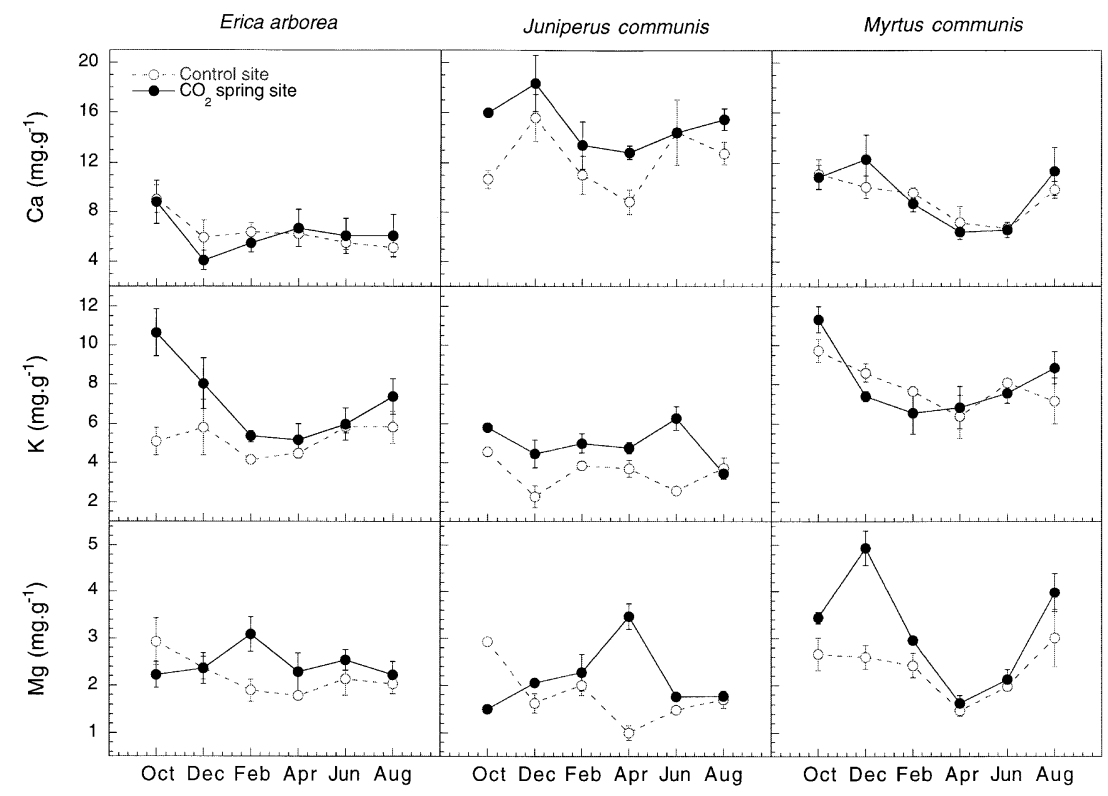

Fig. 3 Seasonal course of the leaf elemental concentrations that were higher at the spring site for at least one of the three studied species. Error bars are \pm SEM. $n=6$ plant samples (several leaves pooled together for each one). which is in disagreement with most previous $\mathrm{CO}_{2}$ experimental studies conducted in less natural shorterterm conditions (Norby et al. 1986; O’Neill et al. 1987a;
Eamus \& Jarvis 1989; Woodin et al. 1992; Berryman et al. 1993; Conroy \& Hocking 1993; Linder \& McDonald 1993; Overdieck 1993; Ceulemans \& Mosseau 1994; Rogers et al. 
Fig. 4 Seasonal course of the leaf elemental concentrations that were lower at the spring site, for at least one of the three studied species. Error bars are \pm SEM. $n=6$ plant samples (several leaves pooled together for each one).

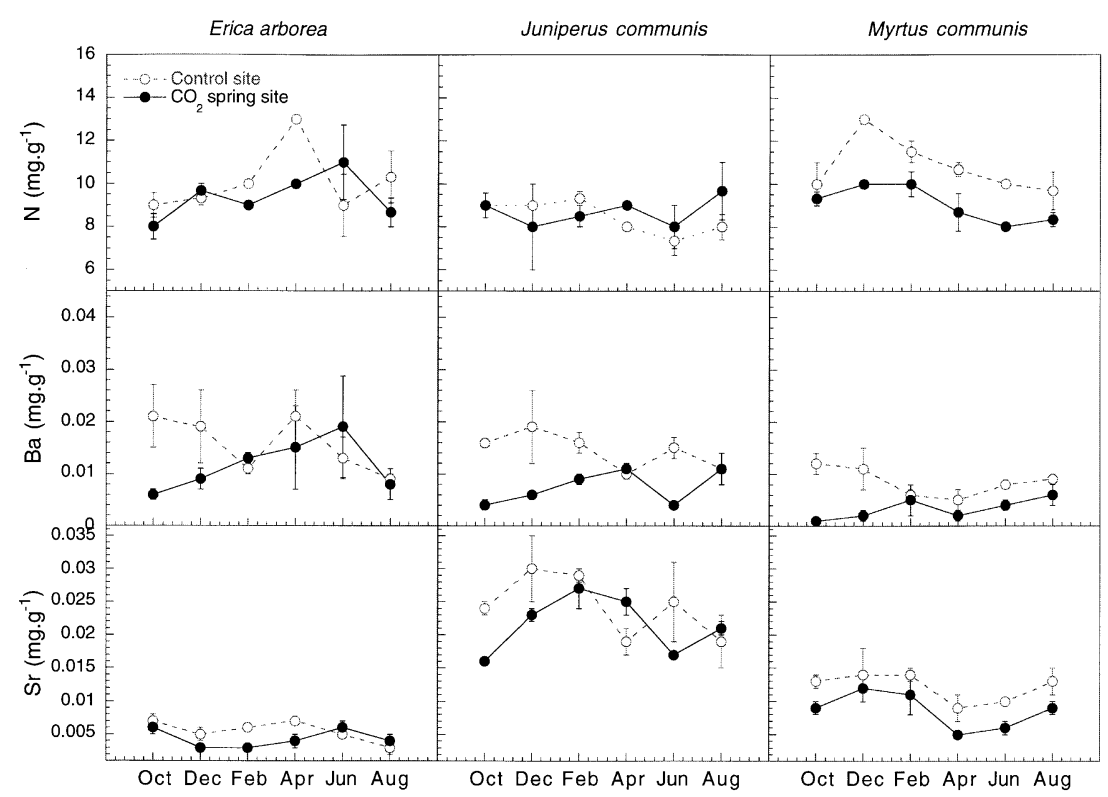

1994; McGuire etal. 1995; Cotrufo etal. 1998; Curtis \& Wang 1998; Roberntz \& Linder 1999).

The results of this investigation show that long-term growth at high concentrations of atmospheric $\mathrm{CO}_{2}$ generated differences in the elemental composition of plant leaves that depend on the species and the elements. Multivariate analysis of element concentrations has been used to characterize nutrient strategies in plants in the framework of ecological niche theory (Garten 1978). In this study, multivariate analysis of element concentrations showed an overall significant difference in leaf elemental concentrations among species and sites. The plots of PC2 vs. PC1 and PC3 vs. PC2 (Fig. 6) separated the three species and the two sites, revealing different strategies with respect to nutrient use among the species, and between the $\mathrm{CO}_{2}$ spring and the control site. The results are also in agreement with isotopic studies of these same species and sites showing different water and nitrogen use (Tognetti \& Peñuelas 2000).

Two of the most-often studied elements in response to growth at high $\left[\mathrm{CO}_{2}\right]$ are $\mathrm{N}$ and $\mathrm{P}$ because of their important nutritional role and indication of general plant nutrient status. In this study, only Myrtus communis showed lower $\mathrm{N}$ concentration and higher $\mathrm{C} / \mathrm{N}$ ratio in plants grown at the $\mathrm{CO}_{2}$ spring site as described in most studies of elevated $\left[\mathrm{CO}_{2}\right]$ effects (McGuire et al. 1995; Peñuelas etal. 1997; Cotrufo etal. 1998; Peñuelas \& Estiarte 1998; Körner 1999). Myrtus communis had the highest $\mathrm{N}$ concentrations, which might be related to the fact that it has relatively deeper roots as indicated by its field water relations (Tognetti etal. 2000b). Myrtus also has a less negative leaf $\delta^{15} \mathrm{~N}$ (Tognetti \& Peñuelas
2000), which also indicated $\mathrm{N}$ use from deeper and more N-saturated soil layers (Lloret et al. 1999; Peñuelas et al. 1999). The decrease in $\mathrm{N}$ concentration at elevated $\left[\mathrm{CO}_{2}\right]$ of the $\mathrm{CO}_{2}$ spring site was not significant in the other two studied species, suggesting caution in the generalization of such response. Similarly, leaf $\mathrm{P}$ concentrations were higher, lower or not different at the $\mathrm{CO}_{2}$ spring site depending on the species (Table 1 ). There are several reports of $\mathrm{P}$ concentration in plant tissues being less influenced than other elements by atmospheric $\mathrm{CO}_{2}$ enrichment or with conflicting data (Norby et al. 1986; Overdieck \& Reining 1986; O'Neill et al. 1987a; Overdieck 1990, 1993; Newbery et al. 1995); thus, these results were not surprising. Similarly variable results were found for other elements. Under elevated $\left[\mathrm{CO}_{2}\right]$ at the spring site there were both greater (e.g. in $\mathrm{Ca}, \mathrm{K}, \mathrm{S}, \mathrm{Mg}, \mathrm{Mn}, \mathrm{Al}, \mathrm{Fe}, \mathrm{P}$ and Ti) and lower (e.g. in $\mathrm{C}, \mathrm{Ba}, \mathrm{Co}, \mathrm{N}, \mathrm{Cr}, \mathrm{Sr}, \mathrm{P}$ and $\mathrm{B}$ ) leaf concentrations depending on the element and the species.

Decreases in the leaf concentrations of some elements were not explained by a simple dilution effect brought about by increased structural carbon (growth) or carbohydrates (Lemon 1983; Mousseau \& Saugier 1992; Idso et al. 1993; Overdieck 1993) because C concentrations also decreased, SLA (measured in Myrtus communis) did not change significantly, and only a few elements decreased their concentration (a dilution would decrease them all). The lower $C$ concentrations in the spring site might be linked to a higher proportion of more oxygenated compounds, such as monosaccharides, relative to less oxygenated compounds, such as polysaccharides under elevated $\left[\mathrm{CO}_{2}\right]$. 

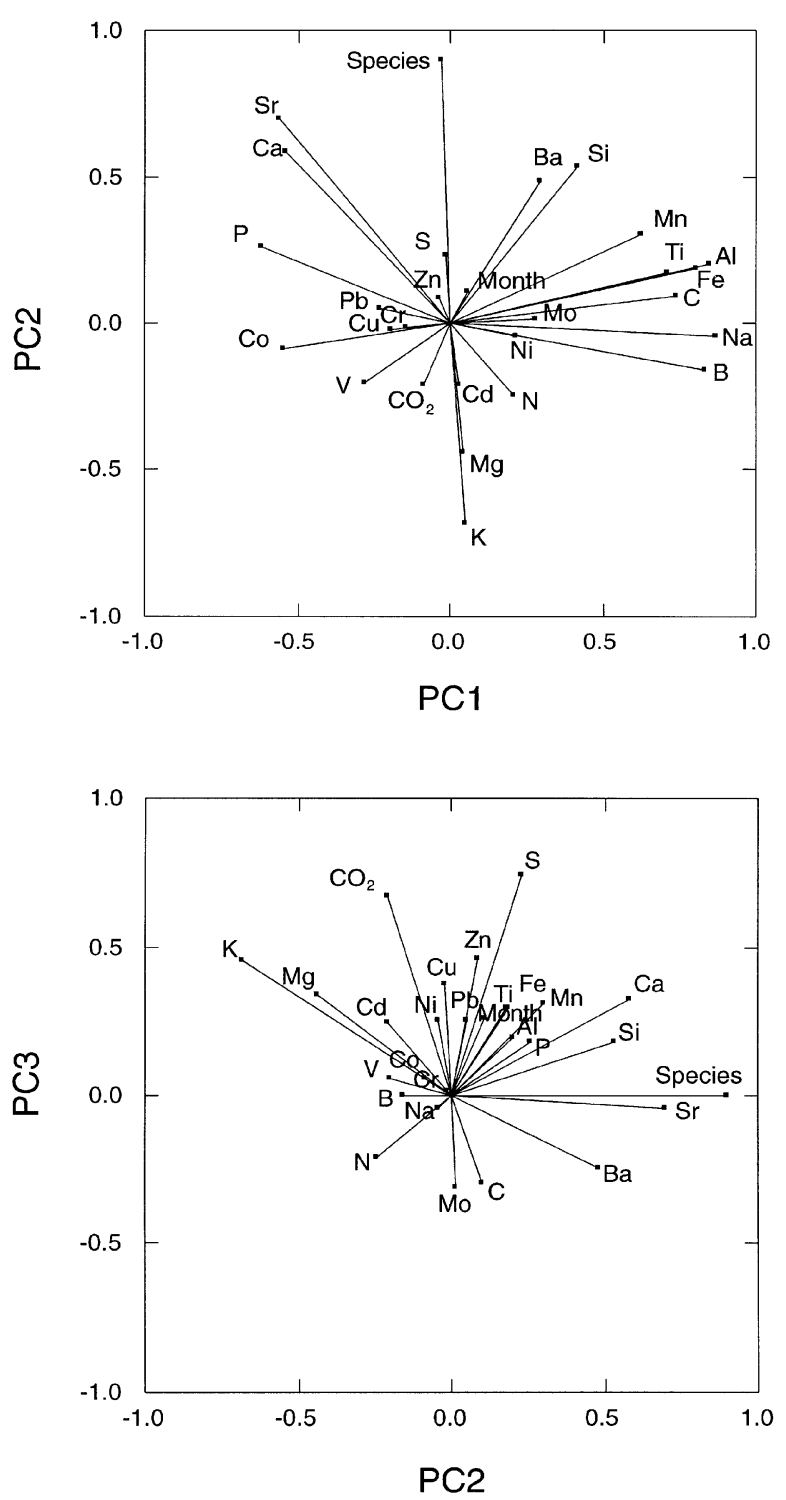

Fig. 5 The leaf concentrations of the different studied elements are presented as a function of the principal component 3 (PC3) and the principal components 1 (PC1) and 2 (PC2) resulting from the multivariate component analysis conducted on the matrix of correlations.

Among the elements with increased concentrations, the largest (up to $700 \%$ in Juniperus communis) and most general (it was present in the three species) was the increase in leaf $\mathrm{S}$ concentration, very likely a consequence of the higher $\left[\mathrm{H}_{2} \mathrm{~S}\right]$ in the spring site (up to $\left.0.04 \mu \mathrm{mol} \mathrm{mol}{ }^{-1}\right)$. Although less clear and less general, there were increases in the concentrations of other elements (Fig. 1). Elevated $\left[\mathrm{CO}_{2}\right]$ may have induced a feedback mechanism whereby elements involved in carbon fixation and carbon transport are retranslocated to the parts of the shrub, such as the leaves, where they are most useful (Roberntz \& Stockfors 1998). The increase in $\mathrm{K}$ or $\mathrm{Mg}$ leaf concentrations could also indicate a decreased export of carbon compounds in the phloem (Cakmak etal. 1994); $\mathrm{K}$ and $\mathrm{Mg}$ may be part of the phloem-loading process and act as counter-ions to negatively charged carbon compounds (Marschner et al. 1996). Lower C concentrations and a speculated higher proportion of mono- and oligosaccharides than polysaccharides at the spring site would also fit this hypothesis. Growth at high $\left[\mathrm{CO}_{2}\right]$ may have increased the capacity for nutrient uptake or have enhanced root growth for enhanced acquisition (O'Neill et al. 1987b). In Juniperus communis the higher concentrations of xylemmobile, phloem-immobile Ca, which is considered to be an indirect indicator of the cumulative transpiration of foliage (Heinze 1973; Aikman \& Houter 1990), might indicate higher transpiration rates in the spring site. Despite similar $\delta^{13} \mathrm{C}$ for atmospheric $\mathrm{CO}_{2}$ at the two sites (M. Saurer, pers. comm.), Tognetti \& Peñuelas (2000) found lower $\delta^{13} \mathrm{C}$ values for $\mathrm{CO}_{2}$ spring plants than for plants at the control site, and similar results have been found by Miglietta et al. (1998) in another $\mathrm{CO}_{2}$ spring site. One might presume that elevated $\left[\mathrm{CO}_{2}\right]$ resulted in lower $\delta^{13} \mathrm{C}$, which indicates lower water-use efficiency, as a result of higher transpiration rates. However, this does not agree with field measurements that show lower stomatal conductance of plants grown at this $\mathrm{CO}_{2}$ spring site (Tognetti etal. 2000b). The depletion of ${ }^{13} \mathrm{C}$, as measured in the products of photosynthesis, is modulated by the rate at which $\mathrm{CO}_{2}$ diffuses into the leaf, but also by the rate at which $\mathrm{CO}_{2}$ is fixed by ribulose1,5-bisphosphate carboxylase/oxygenase. The isotope results may indicate photosynthetic acclimation under the long-term $\mathrm{CO}_{2}$-enriched atmosphere leading to decreased photosynthetic capacity (Miglietta et al. 1998). We have no photosynthetic data for these shrubs, but at the same site the evergreen Quercus ilex showed significant down-regulation and homeostatic adjustment to elevated $\mathrm{CO}_{2}$ (W.C. Oechel and C.L. Hinkson, pers. comm.) in accord with the results of Miglietta et al. 1995) and Oechel \& Vourlitis (1996). This decreased photosynthetic capacity may have been enhanced by water stress, which may have been sufficient to decrease carbon uptake relative to the other elements, i.e. restrict growth more than nutrient uptake. Finally, the (albeit unlikely) possibility that the exposure to low concentrations of $\mathrm{H}_{2} \mathrm{~S}$ may have affected the nutrient physiology for other elements cannot be discarded. Thus, while it is not possible from available data to ascertain the cause or causes, the results do suggest that these shrubs show a long-term adjustment or acclimation in most of their leaf mineral concentrations.

Many authors have noted the potential significance of $\mathrm{CO}_{2}$-induced changes in leaf nutrient quality for herbi- 

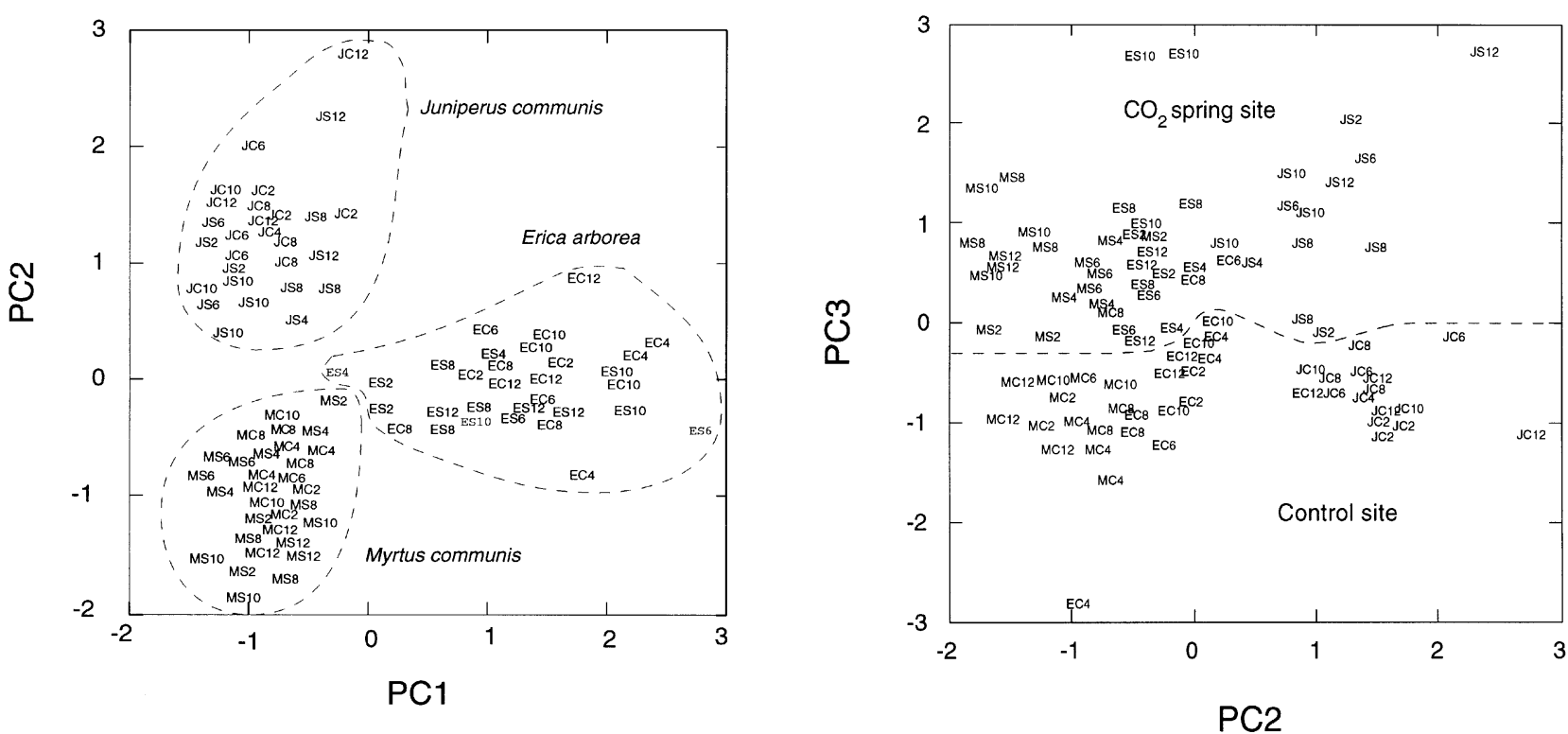

Fig. 6 Separation of sampled plants by species (J, Juniperus communis, E, Erica arborea, and M, Myrtus communis),site (C, Control site, and $\mathrm{S}, \mathrm{CO}_{2}$ spring site) and month (2, February; 4, April; 6, June; 8, August; 10, October; 12, December) by representing them as a function of the principal components 1, 2 and 3 (PC1, PC2, and PC3) resulting from the multivariate component analysis conducted on the matrix of correlations among elemental concentrations.

vore feeding and development (Fajer et al. 1989; Lincoln et al. 1993; Lindroth et al. 1993; Arnone et al. 1995) and for litter decomposition and carbon sequestration in soils (Strain 1985; Rastetter et al. 1992; Comins \& McMurtrie 1993; Schimel 1995). In Myrtus communis the decrease found in $\mathrm{N}$ leaf concentration may result in herbivore stress under conditions of increased $\left[\mathrm{CO}_{2}\right]$ (Lincoln 1993). However, the results of this investigation also show the possibility of greater leaf nutrient contents, depending on the species and element. Therefore, caution should be exercised in attributing decreased leaf nutrient concentrations to elevated $\left[\mathrm{CO}_{2}\right]$, and in linking these decreases to changes in herbivory and decomposition under longterm $\mathrm{CO}_{2}$-exposure.

\section{Conclusions}

There were element- and species-specific, timedependent changes in leaf chemical composition under the elevated $\left[\mathrm{CO}_{2}\right]$ of the spring site. It was also found that reduced elemental concentration is not a general response to long-term exposure to elevated $\left[\mathrm{CO}_{2}\right]$ in these shrubs. Instead, acclimation of $\mathrm{C}$ metabolism to elevated $\left[\mathrm{CO}_{2}\right]$, resulting in little excess $\mathrm{C}$, and changes in nutrient use may sometimes result in increased leaf nutrient concentration. Different growth rates ( $C$ sink) under different interacting environmental conditions or resource availabilities and under seasonal and specific variation must be considered, apart from $\left[\mathrm{CO}_{2}\right]$ itself, when studying the carbon-nutrient relationships under elevated $\left[\mathrm{CO}_{2}\right]$. These results emphasize further the importance of conducting long-term experiments with plants under elevated $\left[\mathrm{CO}_{2}\right]$.

\section{Acknowledgements}

This research was supported by grants CLI97-0344 and CLI990479 from CICYT (Spanish Government).

\section{References}

Aikman DP, Houter G (1990) Influence of radiation and humidity on transpiration: implications for calcium levels in tomato leaves. Journal of Horticultural Science, 65, 245-253.

Arnone JA III, Zaller JG, Ziegler C, Zandt H, Körner C (1995) Leaf quality and insect herbivory in model tropical plant communities after long-term exposure to elevated atmospheric $\mathrm{CO}_{2}$. Oecologia, 104, 72-78.

Berryman CA, Eamus D, Duff GA (1993) The influence of $\mathrm{CO}_{2}$ enrichment on growth, nutrient content and biomass allocation of Maranthes corymbosa. Australian Journal of Botany, 41, 195-209.

Brown KR (1991) Carbon dioxide enrichment accelerates the decline in nutrient status and the relative growth rate of Populus tremuloides Michx. seedlings. Tree Physiology, 81, 161173.

Cakmak I, Engeler C, Marschner H (1994) Partitioning of shoot and root dry matter and carbohydrates in bean plants suffering from phosphorous, potassium and magnesium deficiency. Journal of Experimental Botany, 45, 1245-1250.

di Castri F (1981) Mediterranean-type shrublands of the world. 
In: Ecosystems of the World, Vol. 11: Mediterranean-Type Shrublands (eds di Castri F et al.), pp. 1-52. Elsevier, Amsterdam.

Ceulemans R, Mousseau M (1994) Effects of elevated atmospheric $\mathrm{CO}_{2}$ on woody plants. New Phytologist, 127, 425-446.

Comins HN, McMurtrie RE (1993) Long-term response of nutrient limited forests to $\mathrm{CO}_{2}$ enrichment: equilibrium behavior of plant-soil models. Ecological Applications, 3, 666681.

Conroy J, Hocking P (1993) Nitrogen nutrition of C3 plants at elevated $\mathrm{CO}_{2}$ concentrations. Physiologia Plantarum, 89, 570576.

Cotrufo MF, Ineson P, Scott A (1998) Elevated $\mathrm{CO}_{2}$ reduces the nitrogen concentration of plant tissues. Global Change Biology, $4,43-54$

Curtis PS, Wang X (1998) A meta-analysis of elevated $\mathrm{CO}_{2}$ effects on woody plant mass, form, and physiology. Oecologia, 113, 219-313.

Eamus D, Jarvis PG (1989) The direct effects of increasing the global atmospheric $\mathrm{CO}_{2}$ concentration on natural and comercial temperate trees and forests. Advances in Ecological Research, 19, 1-55.

Fajer ED, Bowers MD, Bazzaz FA (1989) The effects of enriched carbon dioxide atmospheres on plant-insect herbivore interactions. Science, 243, 1198-1200.

Garten ChT Jr (1978) Multivariate perspectives on the ecology of plant mineral element composition. American Naturalist, 112, 533-544.

Hättenschwiler S, Miglietta F, Raschi A, Körner C (1997) Thirty years of in situ tree growth under elevated $\mathrm{CO}_{2}$ : a model for future forest responses? Global Change Biology, 3, 463-471.

Heinze M (1973) The effect of nutrition and water relations on the Ca content in the needles of pine seedlings. Flora, 162, 426436.

Idso SB, Kimball BA, Hendrix DL (1993) Air temperature modifies the size-enhancing effects of atmospheric $\mathrm{CO}_{2}$ enrichment on sour orange tree leaves. Environmental and Experimental Botany, 33, 293-299.

IPCC (1996) Climate Change 1995: the Science of Climate Change (eds Houghton JJ et al.). Cambridge University Press, Cambridge.

Johnson JD, Michelozzi M, Tognetti R (1997) Carbon physiology of Quercus pubescens growing in the Bossoleto $\mathrm{CO}_{2}$ spring of central Italy. In: Plant Responses to Elevated Carbon Dioxide: Evidence from Natural Springs (eds Raschi A et al.), pp. 148-164. Cambridge University Press, Cambridge.

Jones MB, Clifton-Brown J, Raschi A, Miglietta F (1995) The effects on Arbutus unedo L. of long-term exposure to elevated $\mathrm{CO}_{2}$. Global Change Biology, 1, 295-302.

Kattenburg A, Giorgi F, Grassil H et al. (1996) Climate-modelsprojections of future climate. In: Climate Change 1995 - the Science of Climate Change. Contribution of Working Group I to the Second Assesment Report of the Intergovernmental Panel on Climate Change (eds Houghton JT etal.), pp. 285-357. Cambridge University Press, Cambridge.

Körner C (2000) Biosphere responses to $\mathrm{CO}_{2}$-enrichment. Ecological Applications, 10, 1590-1619.

Körner C, Miglietta F (1994) Long term effects of naturally elevated $\mathrm{CO}_{2}$ on mediterranean grassland and forest trees. Oecologia, 99, 343-351.

Larigauderie A, Hilbert DW, Oechel WC (1988) Effect of $\mathrm{CO}_{2}$ enrichment and nitrogen on resource acquisition and resource allocation in a grass, Bromus inollis. Oecologia, 77, 544-549.

Lemon ER (1983). $\mathrm{CO}_{2}$ and Plants. The Response of Plants to Rising Levels of Atmospheric Carbon Dioxide. Westview Press, Boulder, $\mathrm{CO}$.

Lincoln DE (1993) The effect of plant carbon dioxide and nutrient supply on susceptibility to insect herbivores. Vegetatio, 104/105, 273-280.

Lincoln DE, Fajer ED, Johnson RH (1993) Plant-insect herbivore interactions in elevated $\mathrm{CO}_{2}$ environments. Trends in Ecology and Evolution, 8, 64-68.

Linder S, McDonald AJS (1993) Plant nutrition and the interpretation of growth response to elevated concentrations of atmospheric carbon dioxide. In: Design and Execution of Experiments on $\mathrm{CO}_{2}$ Enrichment (eds Schulze ED, Mooney HA), pp. 73-82. Commission of European Communities, Brussels.

Lindroth RL, Kinney KK, Platz CL (1993) Responses of deciduous trees to elevated atmospheric $\mathrm{CO}_{2}$ : productivity, phytochemistry and insect performance. Ecology, 74, 763-777.

Lloret F, Casanovas C, Peñuelas J (1999) Seedling survival of Mediterranean shrubland species in relation to root: shoot ratio, seed and water and nitrogen use. Functional Ecology, 13, 210-216.

Marschner H, Kirby EA, Cakmak I (1996) Effect of mineral nutritional status on shoot-root partitioning of photoassimilates and cycling of mineral nutrients. Journal of Experimental Botany, 47, 1255-1263.

McGuire AD, Melillo JM, Joyce LA (1995) The role of nitrogen in the response of forest net primary production to elevated atmospheric carbon dioxide. Annual Review of Ecology and Systematics, 26, 473-503.

Miglietta F, Raschi A, Bettarini I, Resti R, Selvi F (1993) Natural $\mathrm{CO}_{2}$ springs in Italy: a resource for examining long-term response of vegetation to rising atmospheric $\mathrm{CO}_{2}$ concentrations. Plant, Cell and Environment, 16, 873-878.

Miglietta F, Bandiani M, Bettarini I, van Gardinen P, Selvi F, Raschi A (1995) Preliminary studies of the long-term $\mathrm{CO}_{2}$ response of Mediterranean vegetation around natural $\mathrm{CO}_{2}$ vents. In: Global Change and Mediterranean-Type Ecosystems (eds Moren JM, Oechel WC), pp. 102-120. Springer, New York.

Miglietta F, Bettarini I, Raschi A, Körner C, Vaccari FP (1998) Isotope discrimination and photosynthesis of vegetation growing in the Bossoleto $\mathrm{CO}_{2}$ spring. Chemosphere, 36 (4-5), 771-776.

Mousseau M, Saugier B (1992) The direct effect of increased $\mathrm{CO}_{2}$ on gas exchange and growth of forest tree species. Journal of Experimental Botany, 43, 1121-1130.

Myre R, Camire C (1996) The effect of crown position and date of sampling on biomass, nutrient concentrations and contents of needles and shoots in European larch. Trees, 43, 339-350.

Newbery RM, Wolfwenden J, Mansfield TA, Harrison AF (1995) Nitrogen, phosphorous and potassium uptake and demand in Agrostis capillaris: the influence of elevated $\mathrm{CO}_{2}$ and nutrient supply. New Phytologist, 130, 565-574.

Norby RJ, O'Neill EG, Luxmoore RJ (1986) Effects of atmospheric $\mathrm{CO}_{2}$ enrichment on the growth and mineral nutrition of Quercus alba seedlings in nutrient-poor soil. Plant Physiology, 82, 83-89.

O'Neill EG, Luxmoore RJ, Norby RJ (1987a) Elevated atmospheric $\mathrm{CO}_{2}$ effects on seedling growth, nutrient uptake, and 
rhizosphere bacterial population of Liriodendron tulipifera. Plant and Soil, 104, 3-11.

O'Neill EG, Luxmoore RJ, Norby RJ (1987b) Increases in mycorrizal colonization and seedling growth in Pinus echinata and Quercus alba in an enriched $\mathrm{CO}_{2}$ atmosphere. Canadian Journal of Forest Research, 17, 878-883.

Oechel WC, Vourlitis GL (1996) Direct effects of elevated CO2 on Arctic plant and ecosystem function. In: Carbon Dioxide and Terrestrial Ecosystems (eds Koch GW, Mooney HA), pp. 163176. Academic Press, San Diego, CA.

Oechel WC, Cowles S, Grulke N et al. (1994) Transient nature of $\mathrm{CO}_{2}$ fertilization in Arctic tundra. Nature, 371, 500-503.

Overdieck D (1990) Effects of elevated $\mathrm{CO}_{2}$-concentration levels on nutrient contents of herbaceous woody plants. In: The Greenhouse Effect and Primary Productivity in European AgroEcosystems (eds Goudriaan J et al.), pp. 31-37. Pudoc, Wageningen.

Overdieck D (1993) Elevated $\mathrm{CO}_{2}$ and mineral content of herbaceous and woody plants. Vegetatio, 104/105, 403-411.

Overdieck D, Reining E (1986) Effects of atmospheric $\mathrm{CO}_{2}$ enrichment on perennial ryegrass (Lolium perenne L.) and white clover (Trifolium repens L.) competing in managed model-ecosystems. II. Nutrient uptake. Acta Oecologica/ Oecologia Plantarum, 7, 367-378.

Panichi C, Tongiorgi E (1975) Carbon isotopic composition of $\mathrm{CO}_{2}$ from springs, fumaroles, moffetes and travertines of Central and Southern Italy: a preliminary prospection method of geothermal area. In: Second United Nations Symposium on the Development and Use of Geothermal Resources Vol. 1. , pp. 815825. U.N., San Francisco.

Peñuelas J, Estiarte M (1998) Can elevated $\mathrm{CO}_{2}$ affect secondary metabolism and ecosystem function?. Trends in Ecology and Evolution, 13, 20-24.

Peñuelas J, Matamala R (1990) Changes in N and S leaf content, stomatal density and specific leaf area of 14 plant species during the last three centuries of $\mathrm{CO}_{2}$ increase. Journal of Experimental Botany, 41, 1119-1124.

Peñuelas J, Matamala R (1993) Variations in the mineral composition of herbarium plant species collected during the last three centuries. Journal of Experimental Botany, 44 (266), 1523-1525.

Peñuelas J, Filella I, Terradas J (1999) Variability of plant nitrogen and water use in a $100-\mathrm{m}$ transect of a subdesertic depression of the Ebro valley (Spain) characterized by leaf $\delta^{13} \mathrm{C}$ and $\delta^{15} \mathrm{~N}$. Acta Oecologica, 20, 119-123.

Peñuelas J, Idso SB, Ribas A, Kimball BA (1997) Effects of longterm atmospheric $\mathrm{CO}_{2}$ enrichment on the mineral concentration of Citrus aurantium leaves. New Phytologist, 135, 439-444.

Raiesi FG (1998a) Impacts of elevated atmospheric $\mathrm{CO}_{2}$ on litter quality, litter decomposability and nitrogen turnover rate of two oak species in a Mediterranean forest ecosystem. Global Change Biology, 4, 667-677.

Raiesi FG (1998b) Effects of Elevated Atmospheric $\mathrm{CO}_{2}$ on Soil
Organic Carbon Dynamics in a Mediterranean Forest Ecosystem. PhD dissertation, Wageningen Agricultural University, The Netherlands.

Rastetter EB, McKane RB, Shaver GR, Melillo JM (1992) Changes in $\mathrm{C}$ storage by terrestrial ecosystems: how $\mathrm{C}-\mathrm{N}$ interactions restrict responses to $\mathrm{CO}_{2}$ and temperature. Water, Air, and Soil Pollution, 64, 327-344.

Roberntz P, Linder S (1999) Effects of long term $\mathrm{CO}_{2}$ enrichment and nutrient availability in Norway spruce. II. Foliar chemistry. Trees, 14, 17-27.

Roberntz P, Stockfors J (1998) Effects of elevated $\mathrm{CO}_{2}$ concentration and nutrition on net photosynthesis, stomatal conductance and needle respiration of field-grown Norway spruce trees. Tree Physiology, 18, 233-241.

Rogers HH, Runion CB, Krupa SV (1994) Plant responses to atmospheric $\mathrm{CO}_{2}$ enrichment with emphasis on roots and the rizosphere. Environmental Pollution, 83, 155-189.

Saxe H, Ellsworth DS, Heath J (1998) Tree and forest functioning in an enriched $\mathrm{CO}_{2}$ atmosphere (Tansley Review no. 98). New Phytologist, 139, 395-436.

Schimel DS (1995) Terrestrial ecosystems and the carbon cycle. Global Change Biology, 1, 77-91.

Schulte M (1998) Der Einfluß $\beta$ von erhöhtem atmosphärischen $\mathrm{CO}_{2}$ Konzentrationen auf den S-, $\mathrm{C}$ - und N- Metabolismus verschiedener Quercus species. PhD thesis, University of Freiburg, Germany.

Strain BR (1985) Physiological and ecological controls on carbon sequestering in terrestrial ecosystems. Biogeochemistry, 1, 219232.

Tognetti R (1999) The impact of long-term elevated $\mathrm{CO}_{2}$ concentrations on the water relations, stomatal behaviour and hydraulic architecture of shrubs, and stem growth of trees in a Mediterranean forest ecosystem. PhD dissertation, Trinity College, University of Dublin.

Tognetti R, Peñuelas J (2000) Carbon and nitrogen isotope discrimination in three Mediterranean shrub species cooccurring at a natural $\mathrm{CO}_{2}$ vent. Acta Oecologica, submitted.

Tognetti R, Johnson JD, Michelozzi M, Raschi A (1998) Foliage metabolism in Quercus pubescens and Quercus ilex mature trees with lifetime exposure to local greenhouse effect. Environmental and Experimental Botany, 39, 233-245.

Tognetti R, Cherubini P, Innes J (2000a) Comparative stemgrowth rates of Mediterranean trees under background and naturally enhanced ambient $\mathrm{CO} 2$ concentrations. New Phytologist, 146, 59-74.

Tognetti R, Minnocci A, Peñuelas J, Raschi A, Jones MB (2000b) Comparative field water relations of three Mediterranean shrub species co-occurring at a natural $\mathrm{CO}_{2}$ vent. Journal of Experimental Botany, 51, 1131-1146.

Woodin S, Graham B, Killick A, Skiba U, Cresser M (1992) Nutrient limitation of the long term response of heather Calluna vulgaris (L.) Hull to $\mathrm{CO}_{2}$ enrichment. New Phytologist, 122, 635-642. 